Special issue of the 3rd International Conference on Computational and Experimental Science and Engineering (ICCESEN 2016)

\title{
Temporal Variation of Total Nitrogen and Total Phosphorus in Surface Waters from the Lower Çoruh River Basin, Turkey
}

\author{
A. BAYRAM ${ }^{a, *}$ AND M. KENANOĞLU ${ }^{b}$ \\ ${ }^{a}$ Karadeniz Technical University, Civil Engineering Department, Trabzon, Turkey \\ ${ }^{b}$ General Directorate of State Hydraulic Works, 22. Regional Directorate, Trabzon, Turkey
}

\begin{abstract}
The aim of this study is to monitor and assess the surface water quality in the Lower Coruh River Basin, northeast Turkey. Several key water-quality indicators were measured: total nitrogen, total phosphate phosphorus, chemical oxygen demand, and chlorophyll $a(\mathrm{Chl} a)$. In situ monitoring and the surface water sampling studies in the Çoruh River, the Murgul Stream, and the Borçka Dam Lake were conducted monthly during a period of one year. On an annual basis, the Çoruh River had a little bit higher total nitrogen concentration ranging from $0.335 \mathrm{mg} / \mathrm{l}$ to $1.300 \mathrm{mg} / \mathrm{l}$, but a little bit lower chemical oxygen demand concentration varying between $2.66 \mathrm{mg} / \mathrm{l}$ and $9.12 \mathrm{mg} / \mathrm{l}$, compared to Murgul Stream. Total phosphate phosphorus concentration was almost the same throughout the lower basin and was about $0.090 \mathrm{mg} / \mathrm{l}$. Chl $a$ concentration, which was $1.422 \mu \mathrm{g} / \mathrm{l}$ in Coruh and $1.062 \mu \mathrm{g} / \mathrm{l}$ in Murgul, had shown an increasing trend and reached $3.193 \mu \mathrm{g} / \mathrm{l}$ in the Borçka Dam Lake. The measured results reveal that the Çoruh River and the Murgul Stream have high-quality water, considering total nitrogen and chemical oxygen demand, but slightly polluted water regarding total phosphate phosphorus, with reference to the Turkish Surface Water Quality Regulation. The Borçka Dam Lake was classified as oligotrophic in terms of $\mathrm{Chl} a$, mesotrophic in terms of total nitrogen, and eutrophic in terms of total phosphate phosphorus. Considering the decrease in the annual average values of total nitrogen and chemical oxygen demand, it is concluded that the Borçka Dam Lake had a positive effect on the surface water quality in the Lower Çoruh River Basin.
\end{abstract}

DOI: 10.12693/APhysPolA.132.712

PACS/topics: Borçka Dam Lake, Çoruh River, Murgul Stream, Water Quality

\section{Introduction}

A number of water-quality monitoring studies, including various water-quality indicators have been reported, both nationally [1-3] and internationally [4-6], for different water environments. Nutrients are a concern for water quality of streams, rivers, lakes and dam reservoirs, and the other water bodies. Nitrogen and phosphorus are important water-quality indicators, determining the ecological status of aquatic systems, which cause water quality problems at high concentrations.

The Black Sea is surrounded by six countries located in Asia and Europe: Bulgaria, Georgia, Romania, Russia, Turkey, and Ukraine. The five major Turkish rivers draining into the Southeastern Black Sea are Sakarya, Filyos, Kızılırmak, Yeşilırmak, and Çoruh, respectively. Turkish studies have concentrated on the surface water quality degradation in these basins, with the exception of the Çoruh River Basin, focusing on their nitrogen and phosphorus loads: the Sakarya River Basin [7], the Western Black Sea Basin covering Filyos [8], the Kızılırmak River Basin [9], the Yeşilırmak River Basin [10], and the Eastern Black Sea Basin [11].

\section{Study area}

There are 26 hydrological basins in Turkey. With a mean annual surface water potential of $6300 \times 10^{6} \mathrm{~m}^{3}$ and

*corresponding author; e-mail: adembayram@gmail.com a gross head of $1420 \mathrm{~m}$ for hydroelectric energy generation, the Çoruh River Basin is one of the most important basins in Turkey $[12,13]$.

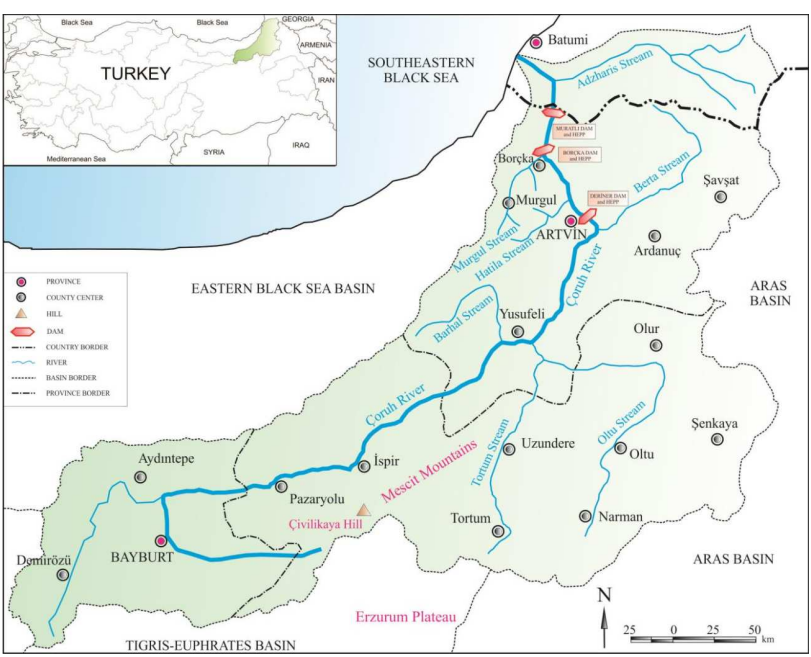

Fig. 1. The Çoruh River Basin, northeast of Turkey.

The Çoruh River, a transboundary river, originates from Çivilikaya Hill, located in the Mescit Mountains in the north Erzurum Plateau, and flows through the Eastern Anatolia and the Eastern Black Sea Region of Turkey to finally reach the Black Sea near Batumi in Georgia $[12,13]$. The major tributaries of the Çoruh River are the Oltu and Tortum streams in Turkey and the Adzharis and Tsakali streams in Georgia (Fig. 1). 
The Coruh is of high economic importance to Turkey, because of its economically exploitable hydropower potential [14]. There are nine hydropower dams, three of which (Yusufeli, Bayram, and Bağlık) are under construction and six of which (Muratlı, Borçka, Deriner, Güllübă, Arkun, and Artvin) are currently operating on the main branch of the Çoruh River. In the Lower Çoruh River Basin, hydroelectric energy generation originally commenced in 2005 with the Muratl Dam and the hydroelectric power plant (HEPP), having an installed capacity of $115 \mathrm{MW}$ and a production of $251.550 \mathrm{GWh}$. This production grew to 2757.076 GWh in 2015 after combining with the HEPPs of the Borçka and Deriner dams [13].

A copper mining facility operates in the catchment area of the Borçka Dam, located in the town of Murgul, Artvin Province. Modern mining at Murgul started in 1945 and was followed by the development of other volcanic-hosted massive sulfide and vein deposits [15]. The plant extracts $>3.5 \times 10^{6}$ metric tons of raw copper ore per year from three open mines and processes 130000 metric tons of copper concentrate, per year. Before the Murgul Waste Dam located on the Lebiskür Stream became operational, $3 \times 10^{6}$ metric tons of waste per year from the copper mining facility were discharged into the Murgul Stream and drained into the Borçka Dam Reservoir, creating an additional sedimentation problem adversely affecting the economic life and water quality of the reservoir [13].

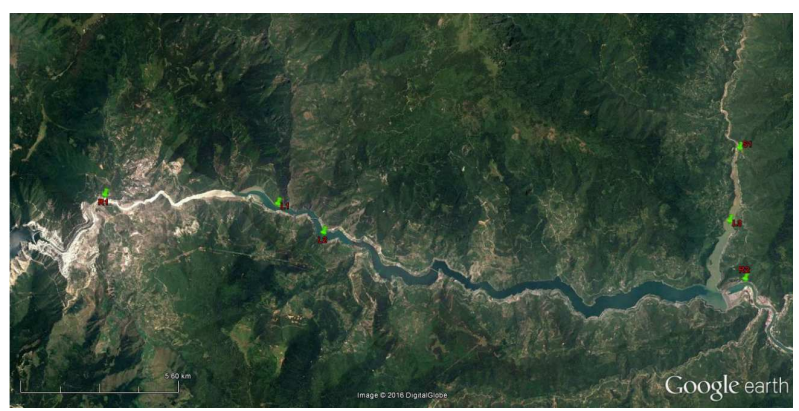

Fig. 2. The study area from the Google Earth, showing the water sampling locations, the Lower Çoruh River Basin.

\begin{tabular}{c|c} 
Stations & Coordinates \\
\hline R1, Çoruh & $41^{\circ} 10^{\prime} 41.71^{\prime \prime} \mathrm{N}-41^{\circ} 50^{\prime} 17.58^{\prime \prime} \mathrm{E}$ \\
$\mathrm{L} 1$, Borçka & $41^{\circ} 13^{\prime} 19.74^{\prime \prime} \mathrm{N}-41^{\circ} 47^{\prime} 22.47^{\prime \prime} \mathrm{E}$ \\
$\mathrm{L} 2$, Borçka & $41^{\circ} 14^{\prime} 22.89^{\prime \prime} \mathrm{N}-41^{\circ} 47^{\prime} 06.39^{\prime \prime} \mathrm{E}$ \\
$\mathrm{L} 3$, Borçka & $41^{\circ} 20^{\prime} 05.45^{\prime \prime} \mathrm{N}-41^{\circ} 39^{\prime} 39.15^{\prime \prime} \mathrm{E}$ \\
$\mathrm{S} 1$, Murgul & $41^{\circ} 19^{\prime} 18.20^{\prime \prime} \mathrm{N}-41^{\circ} 37^{\prime} 59.75^{\prime \prime} \mathrm{E}$ \\
R2, Çoruh & $41^{\circ} 21^{\prime} 02.40^{\prime \prime} \mathrm{N}-41^{\circ} 40^{\prime} 31.73^{\prime \prime} \mathrm{E}$
\end{tabular}

The aim of this study is to monitor and assess the surface water quality in the Lower Çoruh River Basin, Artvin Province, considering several key water-quality indicators: total nitrogen ( $\mathrm{TN})$, total phosphate phosphorus (TP), chemical oxygen demand (COD), and chlorophyll $a(\mathrm{Chl} a)$. The surface water samples $(72)$ were monthly collected from six water sampling stations: S1 in the Murgul Stream, R1 and R2 in the Çoruh River, and L1, L2 and L3 in the Borçka Dam Lake. The sampling stations are shown in Fig. 2, in which the spatial information for each station is given.

\section{Materials and methods}

The study began in December 2010, was conducted monthly, and completed in November 2011. The Chl $a$ was automatically measured and recorded in situ for five minutes at five second intervals using the Hydrolab DS5, equipped with a chlorophyll $a$ sensor. The final result was presented as the arithmetic mean of the 60 readings.

Sampling, preservation, and transport of the water samples to the laboratory were done in alignment with the guidelines of the Standard Methods for the Examination of Water and Wastewater [16]. Plastic sample bottles, pre-cleaned with $1 \mathrm{M} \mathrm{HNO}_{3}$ and rinsed with doubledistilled water, were used to collect the water samples.

The surface water samples were filtered through a cellulose acetate membrane filter with a pore size of $0.45 \mu \mathrm{m}$ under negative pressure at the Hydraulic Laboratory, located in Karadeniz Technical University in Trabzon Province.

TN, TP and COD were measured in the laboratory using a UV-vis spectrophotometer according to the standard methods [16]. The analyses were conducted three times for each sample in a temperature-controlled room $\left(21 \pm 2{ }^{\circ} \mathrm{C}\right)$. The final result was presented as the arithmetic mean of the triplicate analyses.

The intracontinental surface water quality classification and trophic classification system for dam lakes, according to the parameters obtained in this study, following the Turkish Surface Water Quality Regulation (TSWQR), are given in Table I [17].

TABLE I

The surface water quality classification and trophic classification system according to the TSWQR [17].

\begin{tabular}{c|c|c|c|c}
\hline \hline Water quality & $\begin{array}{c}\mathrm{TN} \\
{[\mathrm{mg} / \mathrm{l}]}\end{array}$ & $\begin{array}{c}\mathrm{TP} \\
{[\mathrm{mg} / \mathrm{l}]}\end{array}$ & $\begin{array}{c}\mathrm{COD} \\
{[\mathrm{mg} / \mathrm{l}]}\end{array}$ & $\begin{array}{c}\mathrm{Chl} a \\
{[\mu \mathrm{g} / \mathrm{l}]}\end{array}$ \\
\hline High-quality & 3.5 & $<0.080$ & $<25$ & - \\
Slightly polluted & 11.5 & 0.200 & 50 & - \\
Polluted & 25.0 & 0.800 & 70 & - \\
Highly polluted & $>25.0$ & $>0.800$ & $>70$ & - \\
\hline Trophic level & $\mathrm{TN}$ & $\mathrm{TP}$ & $\mathrm{COD}$ & $\mathrm{Chl} a$ \\
& {$[\mathrm{mg} / \mathrm{l}]$} & {$[\mathrm{mg} / \mathrm{l}]$} & {$[\mathrm{mg} / \mathrm{l}]$} & {$[\mu \mathrm{g} / \mathrm{l}]$} \\
\hline Oligotrophic & $<0.350$ & $<0.010$ & - & $<3.5$ \\
Mesotrophic & 1.000 & 0.050 & - & 15.0 \\
Eutrophic & 1.500 & 0.100 & - & 25.0 \\
Hypertropfic & $>1.500$ & $>0.100$ & - & $>25.0$
\end{tabular}

\section{Results and discussion}

\subsection{Total nitrogen}

The Çoruh River, where TN concentration varied between $0.335 \mathrm{mg} / \mathrm{l}$ and $1.300 \mathrm{mg} / \mathrm{l}$, had a bit higher concentration of TN than the Murgul Stream, where TN 
concentration varied between $0.217 \mathrm{mg} / \mathrm{l}$ and $1.310 \mathrm{mg} / \mathrm{l}$ (Fig. 3). With a mean annual value of $0.536 \mathrm{mg} / \mathrm{l}$, the minimum concentration was determined for the waters released from the Borçka Dam Lake, because of the long hydraulic residence time in the reservoir. The waters from the river and stream are classified as high-quality considering the upper threshold value of $<3.5 \mathrm{mg} / \mathrm{l}$ for TN [17].

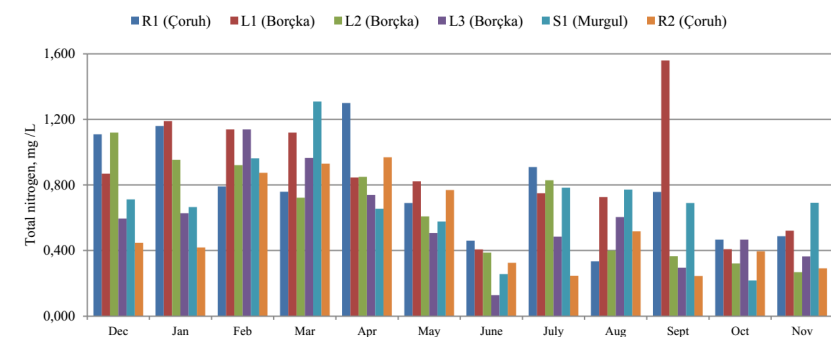

Fig. 3. Temporal variation of total nitrogen in the Lower Çoruh River Basin, northeast of Turkey.

In the Borçka Dam Lake, TN concentration varied between $0.268 \mathrm{mg} / \mathrm{l}$ and $1.560 \mathrm{mg} / \mathrm{l}$. With a mean annual concentration of $0.863 \mathrm{mg} / \mathrm{l}$, the maximum value was determined in L1. Thereafter, TN concentration trended downward, reaching minimum value of $0.577 \mathrm{mg} / \mathrm{l}$ in L3. With reference to the TSWQR [17], the trophic level in the dam lake was determined as mesotrophic.

\subsection{Total phosphate phosphorus}

The Çoruh River, where TP concentration varied between $0.081 \mathrm{mg} / \mathrm{l}$ and $0.100 \mathrm{mg} / \mathrm{l}$, had a slightly lower concentration of TP than the Murgul Stream, where TP concentration varied between $0.080 \mathrm{mg} / 1$ and $0.114 \mathrm{mg} / 1$ (Fig. 4). With reference to the classification of the TSWQR [17], the waters from the river and stream are classified as slightly polluted.

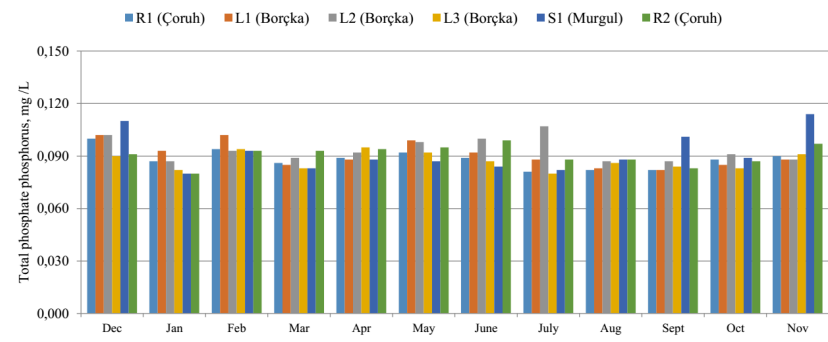

Fig. 4. Temporal variation of total phosphate phosphorus in the Lower Çoruh River Basin, northeast of Turkey.

In the Borçka Dam Lake, TP concentration varied between $0.080 \mathrm{mg} / \mathrm{l}$ and $0.107 \mathrm{mg} / \mathrm{l}$. With a mean annual concentration of $0.087 \mathrm{mg} / \mathrm{l}$, the minimum value was determined in L3. With reference to the TSWQR [17], the trophic level in the dam lake was determined as eutrophic.

\subsection{Chemical oxygen demand}

The Çoruh River, where COD concentration varied between $2.66 \mathrm{mg} / \mathrm{l}$ and $9.12 \mathrm{mg} / \mathrm{l}$, had a lower concentration of COD than the Murgul Stream, where COD concentration varied between $3.48 \mathrm{mg} / 1$ and $11.8 \mathrm{mg} / 1$ (Fig. 5). With a mean annual concentration of $4.97 \mathrm{mg} / \mathrm{l}$, the minimum value was determined for the water released from the Borçka Dam Lake because of the long hydraulic residence time in the reservoir. The waters from the river and stream are classified as high-quality considering the upper threshold value of $<25 \mathrm{mg} / \mathrm{l}$ for COD [17].

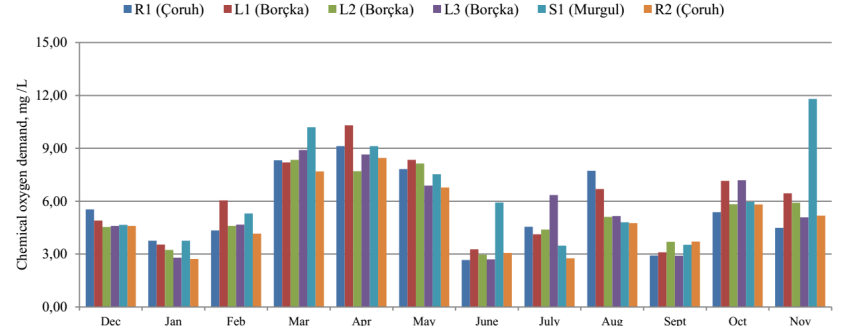

Fig. 5. Temporal variation of chemical oxygen demand in the Lower Çoruh River Basin, northeast of Turkey.

In the Borçka Dam Lake, COD concentration varied between $2.70 \mathrm{mg} / \mathrm{l}$ and $10.3 \mathrm{mg} / \mathrm{l}$. With a mean annual concentration of $5.37 \mathrm{mg} / \mathrm{l}$, the minimum value was determined in L2. No trophic classification is available in terms of COD for dam lakes. However, the surface waters from the lake have high-quality considering the intracontinental surface water quality classification [17].

\subsection{Chlorophyll a}

The Çoruh River, where Chl a concentration varied between $0.573 \mu \mathrm{g} / \mathrm{l}$ and $3.764 \mu \mathrm{g} / \mathrm{l}$, had a bit higher concentration of Chl $a$ than the Murgul Stream, where Chl $a$ concentration varied between $0.280 \mu \mathrm{g} / \mathrm{l}$ and $1.848 \mu \mathrm{g} / \mathrm{l}$ (Fig. 6). No classification for Chl $a$ is available in the TSWQR [17].

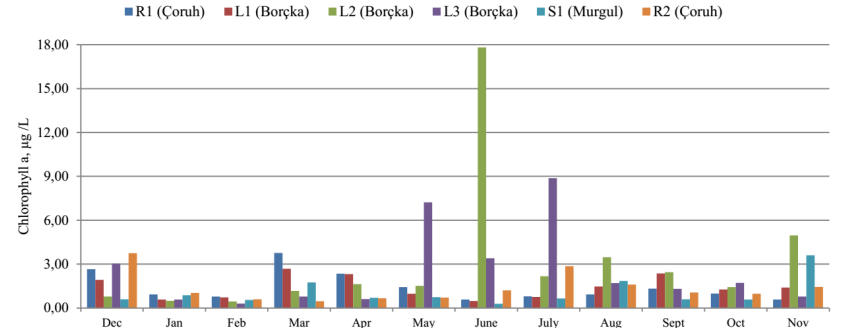

Fig. 6. Temporal variation of chlorophyll $a$ in the Lower Çoruh River Basin, northeast of Turkey.

In the Borçka Dam Lake, Chl a concentration fluctuated between $0.300 \mu \mathrm{g} / \mathrm{l}$ and $17.82 \mu \mathrm{g} / \mathrm{l}$. With a mean annual concentration of $3.193 \mu \mathrm{g} / \mathrm{L}$, the maximum value was determined in L2. With reference to 
the TSWQR [17], the trophic level in the dam lake was determined as oligotrophic.

The basic statistics of the TN, TP, COD and Chl $a$ concentrations in the Lower Çoruh River Basin are given in
Table II, where surface water quality classification is also provided for the Çoruh River and the Murgul Stream, as well as trophic classification system for the Borçka Dam Lake.

TABLE II

The water quality variation and classification in the Lower Çoruh River Basin, northeast of Turkey.

\begin{tabular}{|c|c|c|c|c|c|c|c|c|c|c|}
\hline \multirow[b]{2}{*}{ Stations } & \multicolumn{4}{|c|}{$\begin{array}{c}\mathrm{TN} \\
{[\mathrm{mg} / \mathrm{l}]}\end{array}$} & \multirow{2}{*}{$\begin{array}{l}\text { Water quality } \\
\text { or } \\
\text { Trophic level }\end{array}$} & \multicolumn{4}{|c|}{$\begin{array}{c}\mathrm{TP} \\
{[\mathrm{mg} / \mathrm{l}]}\end{array}$} & \multirow{2}{*}{$\begin{array}{l}\text { Water quality } \\
\text { or } \\
\text { Trophic level }\end{array}$} \\
\hline & Min & $\operatorname{Max}$ & Mean & SD & & Min & $\operatorname{Max}$ & Mean & SD & \\
\hline $\mathrm{R} 1$ & 0.335 & 1.300 & 0.769 & 0.306 & High-quality & 0.081 & 0.100 & 0.088 & 0.005 & Slightly polluted \\
\hline L1 & 0.407 & 1.560 & 0.863 & 0.344 & Mesotrophic & 0.082 & 0.102 & 0.091 & 0.007 & Eutrophic \\
\hline L2 & 0.268 & 1.120 & 0.646 & 0.291 & Mesotrophic & 0.087 & 0.107 & 0.093 & 0.007 & hic \\
\hline L3 & 0.295 & 1.140 & 0.557 & 0.278 & Mesotrophic & 0.080 & 0.095 & 0.087 & 0.005 & Eutrophic \\
\hline S1 & 0.217 & 1.310 & 0.691 & 0.286 & High-quality & 0.080 & 0.114 & 0.092 & 0.011 & Slightly polluted \\
\hline $\mathrm{R} 2$ & 45 & 0.969 & 0.536 & 0.274 & Hig & 80 & 0.110 & 0.092 & 0.008 & Slightly polluted \\
\hline \multirow[b]{2}{*}{ Stations } & \multicolumn{4}{|c|}{$\begin{array}{c}\mathrm{COD} \\
{[\mathrm{mg} / \mathrm{l}]}\end{array}$} & Water quality & \multicolumn{4}{|c|}{$\begin{array}{c}\mathrm{Chl} a \\
{[\mu \mathrm{g} / \mathrm{l}]}\end{array}$} & $\begin{array}{c}\text { Water quality } \\
\text { or }\end{array}$ \\
\hline & Min & Max & Mean & $\mathrm{SD}$ & Trophic level & Min & Max & Mean & SD & Trophic level \\
\hline $\mathrm{R} 1$ & 2.66 & 9.12 & 5.55 & 2.18 & High-quality & 0.573 & 3.764 & 1.422 & 0.989 & - \\
\hline L1 & 3.10 & 10.30 & 6.01 & 2.29 & - & 0.470 & 2.688 & 1.409 & 0.757 & Oligotr \\
\hline L2 & 2.96 & 8.34 & 5.37 & 1.86 & - & 0.440 & 17.820 & 3.193 & 4.786 & Oligotrophic \\
\hline L3 & 2.70 & 8.90 & 5.49 & 2.15 & - & 0.300 & 8.880 & 2.525 & 2.778 & Oligotrophic \\
\hline S1 & 3.48 & 11.80 & 6.34 & 2.75 & High-quality & 0.280 & 1.848 & 1.062 & 0.932 & - \\
\hline $\mathrm{R} 2$ & 2.72 & 8.45 & 4.97 & 1.90 & High-quality & 0.458 & 3.752 & 1.361 & 0.987 & - \\
\hline
\end{tabular}

\section{Conclusions}

There are five Turkish rivers draining into the Southeastern Black Sea, one of which is the Çoruh River, where scientific studies have concentrated on the hydropower energy and flood frequency analysis. In this study, the surface water quality in the Lower Çoruh River Basin were monitored and assessed, considering several key water-quality indicators, such as total nitrogen, total phosphate phosphorus, chemical oxygen demand, and chlorophyll $a$.

The obtained results have revealed that the Çoruh River and the Murgul Stream had high-quality water, considering TN and COD, but slightly polluted water regarding TP, with reference to the Turkish Surface Water Quality Regulation. The Borçka Dam Lake was classified as oligotrophic in terms of $\mathrm{Chl} a$, mesotrophic in terms of TN, and eutrophic in terms of TP, respectively. Considering the decrease in the annual average values, it was concluded that the dam lake had a positive effect on the river and stream water quality in terms of TN and COD.

Coastal eutrophication have been a serious problem in many coastal waters, especially in land-locked inland seas, for a long time, and the Black Sea is the largest one of these seas, with eutrophication problems. These are due to nutrients, such as nitrogen and phosphorus, delivered by the rivers, sewage systems, etc., in increasing amounts, to the coastal waters of the Black Sea. Therefore, a specific water monitoring and sampling station should be selected at the Çoruh River mouth in Georgia to determine the nitrogen and phosphorus, as well as carbon export by this transboundary river to the Southeastern Black Sea together with a long term monitoring.

\section{Acknowledgments}

This study was funded by the Scientific Research Projects Unit of Karadeniz Technical University, project no. 941. This paper is dedicated to the memory of the late Assoc. Prof. Dr Murat İhsan Kömürcü: a top researcher, a good person, and a beloved friend. The authors feel indebted to Deniz Kenanoğlu accompanying in situ measurement and surface water sampling studies (General Directorate of State Hydraulic Works, 22. Regional Directorate, Trabzon Province, Turkey) and Zeki Aydemir operating the recreational boats (Artvin Municipality, Artvin Province, Turkey).

\section{References}

[1] M. Yilmaz, A. Usta, Fresenius Environ. Bull. 24, $1614(2015)$

[2] M.F. Kutluozturk, M. Dogru, Acta Phys. Pol. A 128, B-397 (2015)

[3] I.S. Uncu, M. Akdurul, Acta Phys. Pol. A 130, 293 (2016). 
[4] A. Raike, O.P. Pietilainen, S. Rekolainen, P. Kauppila, H. Pitkanen, J. Niemi, A. Raateland, J. Vuorenmaa, Sci. Total Environ. 310, 47 (2003).

[5] M. Wiatkowski, C. Rosik-Dulewska, K. Kuczewski, R. Kasperek, Rocznik Ochorona Srodowiska 15, 2666 (2013).

[6] M. El Tokhi, B.M. Amin, S. Alaabed, Acta Phys. Pol. A 130, 138 (2016).

[7] The Sakarya River Basin Action Plan Report, General Directorate of Water Management, accessed 10 November 2016, Turkey 2013 (in Turkish).

[8] The Western Black Sea Basin Action Plan Report, General Directorate of Water Management, accessed 10 November 2016, Turkey 2013 (in Turkish).

[9] The Kizllırmak River Basin Action Plan Report, General Directorate of Water Management, accessed 10 November 2016, Turkey 2010 (in Turkish).

[10] The Yesillrmak River Basin Action Plan Report, General Directorate of Water Management, accessed 10 November 2016, Turkey 2010 (in Turkish).

[11] The Eastern Black Sea Basin Action Plan Report, General Directorate of Water Management, accessed 10 November 2016, Turkey 2013 (in Turkish).
[12] DSI, State Water Works 2006, Yusufeli Dam and HEPP project environmental impact assessment report, General Directorate of State Hydraulic Works, accessed 10 November 2016, Ankara 2006.

[13] A. Bayram, M. Kenanoglu, Lake Reservoir Manage. 32, 209 (2016).

[14] A. Kibaroglu, A. Klaphake, A. Kramer, W. Scheumann, A. Carius, Cooperation on Turkey's transboundary waters, Status Report commissioned by the German Federal Ministry for Environment, Nature Conservation and Nuclear Safety, Project No: 903 19:226, Berlin 2005.

[15] M. Akcay, C.J. Moon, Geochem.: Exploration Environ. Anal. 4, 317 (2004).

[16] APHA, American Public Health Association, Standard methods for the examination of water and wastewater, 18th ed., Washington 1992.

[17] TSWQR, Turkish Surface Water Quality Regulation, The Official Gazette no: 29797, accessed 10 November 2016, Turkey 2016 (in Turkish). 